\title{
A Single Currency for Pacific Island Countries: a Revisit
}

\author{
T.K. Jayaraman \\ The University of the South Pacific, Fiji Islands \\ Chee-Keong Choong \\ Universiti Tunku Abdul Rahman, Malaysia
}

\begin{abstract}
This paper re-visits the subject of a common currency for the Pacific region, comprising 14 Pacific island countries (PICs) and the region's two advanced countries, Australia and New Zealand. The PICs are highly dependent on Australia and New Zealand for trade in goods and services and aid inflows. Earlier studies on regional common currency, which dealt with certain aspects of the optimum currency area conditions, took into consideration three kinds of shocks, namely shocks in world output, domestic output and price levels. Since PICs' growth is influenced by regional developments to a larger degree than by world developments, this paper takes into consideration regional shocks, in addition to shocks in global and national outputs. Using variance decomposition analysis in this paper we investigate whether PICs and the region's two advanced countries could be suitable candidates for a currency union.
\end{abstract}

-JEL Classification : A15, C32, F36, F42

- Key Words: optimum currency area, shocks, pacific island countries, Australia and New Zealand

\footnotetext{
*Corresponding address: T. K. Jayaraman: School of Economics, Faculty of Business and Economics, The University of the South Pacific, Laucala Campus, Laucala Bay Road, Suva, Fiji Islands, Tel: +679323-2178/2547, Fax:+679-323-2522/1506, e-mail: Jayaraman_tk@usp.ac.fj, Chee-Keong Choong: Department of Economics, Faculty of Business and Finance, Universiti Tunku Abdul Rahman (Perak Campus), Jalan Universiti, Bandar Barat, 31900 Kampar, Perak Darul Ridzuan, Malaysia, Tel: +6034662323, Fax:+603-4661313, e-mail: choonck@utar.edu.my.
} 


\section{Introduction}

Regional integration of Pacific island countries (PICs) has been the objective ever since their leaders joined hands with the two advanced countries in the region, Australia and New Zealand to establish in 1971 a regional organization known as South Pacific Islands Forum. This Forum underwent a name change in October 2000 to Pacific Islands Forum, and is now known as the Forum (Jayaraman 2001).

The Forum ${ }^{1}$ comprises 16 members: Australia and New Zealand, and 14 independent PICs, which are: Cook Islands, Fiji, Kiribati, Marshall Islands, Federated States of Micronesia, Nauru, Niue, Papua New Guinea, Samoa, Solomon Islands, Tonga, Tuvalu and Vanuatu. Recent initiatives towards promoting deeper integration derived inspiration from the birth of the new currency, the euro in 1999, heralding the arrival of the new Millennium. These initiatives included the signing of two agreements in 2002, one known as the Pacific Island Countries Trade Agreement (PICTA), aimed at ushering in free trade amongst all PICs by 2010, and the other as Pacific Agreement on Closer Economic Cooperation (PACER) for promoting by 2015, intensive economic cooperation between PICs and Australia and New Zealand (Jayaraman 2005).

The idea of a common, regional currency was floated during the annual Forum Leaders' meeting in Auckland in August 2003, which was attended by the heads of member governments. As the subject did not officially figure in the agenda of the meeting, it was not formally discussed. However, it was apparent that Australia was keen to adopt a common currency, as a step towards bringing about greater fiscal and monetary discipline. The timing of the proposal for a common currency was triggered by certain global and regional developments. They included the perceived terror threat to the region and failure of some PICs in maintaining peace and order. Furthermore, the deteriorating economic conditions in some of island states due to weak economic policies and poor governance were causing concerns to donors in regard to aid effectiveness (Hughes 2003), which prompted an Australian Senate Committee (2003) to come up with a strong plea for a Pacific Economic and Political Community. One of the recommendations made by the Australian Senate Committee for promoting regional stability was adopting a common currency, preferably the Australian dollar, replacing the existing national currencies.

\footnotetext{
${ }^{1}$ Australia, as the largest and richest member of the Forum, bears a major proportion of its administrative costs. Further, it plays a lead role as a significant provider of foreign aid to PICs.
} 
Earlier studies on a common currency for PICs, which applied the optimum currency criteria (Mundell 1961) in their investigations, did not specifically focus on impact of regional growth developments on PICs. In the context of island nations' heavy dependency on the region's two advanced countries for trade and tourism, it appears appropriate to consider the impact of regional output shocks on each PIC. Accordingly, this paper is motivated to re-visit the subject. The objective of the paper is to study the impact of regional output shocks, besides the global and country specific output shocks on PICs, with a view to evaluating their suitability to form a currency union.

The paper is organized on the following lines: section II undertakes a very brief review of the literature on the subject; section III outlines the methodology while section IV reports and interprets the results. Section V presents some conclusions with policy implications.

\section{Review of Empirical Literature Review on Single Currency for the Pacific Region}

In the event of the Australian dollar being adopted as the common currency of the region, the cost for Australia would be minimal since its central bank, the Reserve Bank of Australia (RBA) would continue with unfettered freedom to pursue its own monetary policy. Substantial benefits to Australia would consequently arise from increase in its volume of trade, since dollarization of the region would lead to elimination of transaction costs and volatility in exchange rates, between Australia and others in the region.

As Alesena and Barro (2001) noted, just as a common language promotes communication among people, a common currency could promote trade and investment among countries in the region. These benefits will have to be weighed against the likely costs that have to be incurred by other Forum members. The costs would include the costs of discontinuing their own independent currencies by replacing with the Australian dollar and the loss of seigniorage revenue from printing their own currencies. Further, all of them will have to fall in line with Australian macroeconomic and exchange rate policies.

A common currency entails a single set of economic, monetary, financial and fiscal policies to influence the balance of payments of the region. Such a single set of policies can be justified only when there is a high degree of synchronization of business cycles for all prospective member countries of a currency union. 
According to Mundell's seminal contribution (1961), known as optimum currency area (OCA) conditions, countries experiencing common external shocks would be better suited to form a currency union because it permits the use of union-wide policies to correct any imbalances, including the adjustment of the common currency. The OCA conditions have since been elaborated, refined and updated by growing literature on the subject (Bayoumi and Eichengreen 1993, 1994; Bayoumi, Eichengreen and Mauro 2000; Bayoumi and Ostry 1997; Bayoumi and Mauro 1999; Eichengreen and Bayoumi, 1999; International Monetary Fund 2001, 1997).

In regard to the adoption the Australian dollar as common currency, a former Governor of New Zealand's central bank (Brash 2000), went on record in 2000 that the time for adopting the Australian dollar by New Zealand as a common currency was not ripe. Arguing along the lines of OCA conditions, he observed that there had been a lack of synchronization of business cycles between Australia and New Zealand during the recent past. In addition to the availability of a regional central banker's point of view, there have been some academic studies as well on the feasibility of a currency union between the two countries. These include Crosby and Otto (2003), Coleman (1999), Hargraves and McDermott (1999), Grimes, et al. (1998). Their findings were, however, not unanimous. While Grimes et al. (1998) felt that a common currency for Australia and New Zealand would be beneficial, Crosby and Otto (2003) opined otherwise. Arguing from the Australian point of view, Crosby and Otto (2003) concluded that (i) Australia and New Zealand were not suitable candidates for the currency union; (ii) the benefits of a currency union for Australia would be small; and (iii) it would be worthwhile to consider currency union with the United States rather than with New Zealand.

The feasibility of a common currency for PICs, whose key economic indicators are given in Table 1, has been studied intensively in recent years by various researchers. Table 2 lists the issues examined by various authors. De Brouwer (2000), Chand (2003), Duncan $(2002,2005)$, Jayaraman $(2001,2005)$ came to a general agreement that due to the existence of substantial trade between Australia and PICs, the gains from adopting the Australian dollar, as common currency would be large. Additionally, De Brouwer (2000) and Duncan (2002, 2005) highlighted the gains arising out of currency union in terms of favorable outcomes, such as institutional efficiencies, including entrusting the responsibility of formulation and implementation of common monetary policies to Reserve Bank of Australia. Such an outcome would release the limited, skilled human resources presently employed in the central banks for re-deployment in other productive 
Table 1. Selected Key Economic and Social Indicators

\begin{tabular}{|c|c|c|c|c|c|c|c|c|}
\hline \multirow[b]{2}{*}{ Regions } & \multirow[b]{2}{*}{$\begin{array}{c}\text { Population } \\
\text { ('000) } \\
2006\end{array}$} & \multirow[b]{2}{*}{$\begin{array}{c}\text { Area } \\
(' 000) \\
\text { Sq. km }\end{array}$} & \multirow{2}{*}{$\begin{array}{c}\text { Per Capita } \\
\text { GDP } \\
\text { (Current } \\
\text { Prices) } \\
\text { in US\$ } \\
2006 \\
\end{array}$} & \multirow[b]{2}{*}{$\begin{array}{l}\text { Human } \\
\text { Develop- } \\
\text { ment } \\
\text { Index } \\
\text { Ranking } \\
2003 \\
\end{array}$} & \multirow[b]{2}{*}{$\begin{array}{l}\text { Vulnerability } \\
\text { Index } \\
\text { Ranking } \\
2000\end{array}$} & \multirow[b]{2}{*}{$\begin{array}{c}\text { Aid } \\
\text { Per Capita } \\
\text { in US\$ } \\
2004\end{array}$} & \multicolumn{2}{|c|}{ Aid } \\
\hline & & & & & & & $\begin{array}{l}\% \text { of } \\
\text { GDP } \\
1990\end{array}$ & $\begin{array}{l}\% \text { of } \\
\text { GDP } \\
2004\end{array}$ \\
\hline $\begin{array}{l}\text { Cook } \\
\text { Islands }\end{array}$ & 22 & 0.2 & 7,549 & 62 & NA & 490.0 & NA & 28.0 \\
\hline Fiji & 853 & 18.3 & 3,306 & 92 & 8 & 76.0 & 3.9 & 2.6 \\
\hline $\begin{array}{l}\text { Fed States } \\
\text { of Micron- } \\
\text { esia }\end{array}$ & 111 & 0.7 & 2,205 & 120 & NA & 787.0 & NA & 36.0 \\
\hline Kiribati & 101 & 0.7 & 703 & 129 & 59 & 171.0 & 22,5 & 17.8 \\
\hline Palau & 20 & 0.5 & 7.765 & NA & NA & 978.0 & NA & 15.0 \\
\hline $\begin{array}{l}\text { Papua New } \\
\text { Guinea }\end{array}$ & 5,995 & 462 & 943 & 137 & 30 & 46.0 & 7.2 & 7.6 \\
\hline $\begin{array}{l}\text { Republic of } \\
\text { Marshall } \\
\text { Island }\end{array}$ & 65 & 0.2 & 2,363 & 121 & NA & 836.0 & 49.6 & 37.4 \\
\hline Samoa & 186 & 2.8 & 2.277 & 74 & 20 & 167.0 & 42.6 & 8.2 \\
\hline $\begin{array}{l}\text { Solomon } \\
\text { Islands }\end{array}$ & 489 & 28.9 & 684 & 128 & 11 & 262.0 & 21.7 & 47.8 \\
\hline Tonga & 102 & 0.7 & 2.176 & 54 & 3 & 109.0 & 26.3 & 9.1 \\
\hline Tuvalu & 11 & 0.003 & 1.346 & 118 & NA & 260.0 & 47.2 & 45.0 \\
\hline Vanuatu & 215 & 12.2 & 1,799 & 118 & 1 & 162.0 & 33.0 & 12.4 \\
\hline
\end{tabular}

spheres in the economy in each PIC.

Other studies (Jayaraman 2001, 2003, 2005) point out to the gains of currency union, which emanate from the reduction in transaction costs by way of elimination of currency conversion and from the absence of any volatility in exchange rates. In the context of PICs' weak banking infrastructure and poor electronic communication systems, gains from elimination of transaction costs involved in conversion of one currency into another would continue to be a dominant component of benefits of a single currency.

Based on a correlation coefficients analysis, Bowman (2002) observed that except for Tongan currency, movements in currencies of PICs were more correlated with the American dollar than with Australian dollar and therefore concluded against adopting Australian dollar as common currency.

It was argued by Ward and Jayaraman (2006) that since external shocks in the past affecting the PICs and the two developed countries in the region were 
Table 2. Major Issues Examined by Studies on Single Currency for PICs

\begin{tabular}{|c|c|}
\hline No. Studies by Authors & Issues Examined \\
\hline 1. Bowman (2004) & $\begin{array}{l}\text { (i) Relationship between currencies of PICs and the Australian dollar, } \\
\text { Japanese yen, the British pound and the US dollar; } \\
\text { (ii) trade relationships between PICs and Australia, and PICs and } \\
\text { Asia. }\end{array}$ \\
\hline $\begin{array}{l}\text { 2. De Brouwer } \\
(2000)\end{array}$ & $\begin{array}{l}\text { (i) movements in real exchange rates of selected PICs and Australia; } \\
\text { (ii) labour mobility; } \\
\text { (iii) capital mobility; } \\
\text { (iv) fiscal transfers }\end{array}$ \\
\hline 3. Chand (2003) & $\begin{array}{l}\text { (i) trade relationships between PICs and Australia; } \\
\text { (ii) political economy }\end{array}$ \\
\hline $\begin{array}{l}\text { Duncan } \\
(2002,2005)\end{array}$ & $\begin{array}{l}\text { (i) political economy } \\
\text { (ii) monetary sovereignty } \\
\text { (iii) fiscal discipline } \\
\text { (iv) movements in real exchange rates of PICs and Australia } \\
\text { (v) coincidence of business cycles }\end{array}$ \\
\hline 5. Jayaraman (2001) & $\begin{array}{l}\text { (i) Optimal currency area criteria applicability volume, degree of } \\
\text { product diversification, factor mobility, similarity in inflation rates } \\
\text { and correlation in economic activities }\end{array}$ \\
\hline 6. Jayaraman (2003) & (i) Empirical Testing of optimal area conditions \\
\hline 7. Jayaraman (2004) & $\begin{array}{l}\text { (i) seigniorage revenue loss } \\
\text { (ii) fiscal transfers }\end{array}$ \\
\hline 8. Jayaraman (2005) & $\begin{array}{l}\text { (i) tests of indicators in terms of correlations of growth rates, interest } \\
\text { rates and exchange rates }\end{array}$ \\
\hline 9. Jayaraman (2006) & (i) patterns of shocks \\
\hline $\begin{array}{l}\text { Ward and Jayara- } \\
\text { man (2006) }\end{array}$ & $\begin{array}{l}\text { (i) impacts of shocks } \\
\text { (ii) SVAR approach }\end{array}$ \\
\hline $\begin{array}{l}\text { Bunyaratavej and } \\
\text { Jayaraman }(2007)\end{array}$ & (i) convergence of growth rates \\
\hline $\begin{array}{l}\text { Jayaraman, et al. } \\
\text { (2007) }\end{array}$ & (i) convergence of nominal and real exchange rate movements \\
\hline
\end{tabular}

asymmetrical in nature, one common set of monetary, fiscal and exchange rate policies would not serve any PIC's interest and hence PICs were not found suitable candidates for a currency union either with Australia or New Zealand. In their study, Ward and Jayaraman (2006) focused on three kinds of shocks in world output, domestic output and domestic price level.

Table 3 provides details of trade in goods amongst PICs (referred to a sintraregional trade) and each PIC's trade with Australia and New Zealand. While intraregional trade exclusively amongst PICs, without involving Australia, is low in terms of percentage of total trade, each PIC's imports from or exports to Australia and New Zealand land are relative large. For example, in 2007, about 66 per cent 
Table 3. Intra-regional Exports and Imports of PICs

\begin{tabular}{|c|c|c|c|c|c|c|c|c|}
\hline Countries & & $\begin{array}{l}\text { Intra-Reg } \\
\text { Exports } \\
\text { (\% of Total } \\
\text { Exports) }\end{array}$ & $\begin{array}{l}\text { Imports } \\
\text { (\% of Total } \\
\text { Imports) }\end{array}$ & $\begin{array}{l}\text { Intra-Reg } \\
\text { Trade } \\
\text { (\% of Total } \\
\text { Trade) }\end{array}$ & $\begin{array}{l}\text { Exports to } \\
\text { Australia } \\
\text { (\% of Total } \\
\text { Exports) }\end{array}$ & $\begin{array}{l}\text { Imports from } \\
\text { Australia } \\
\text { (\% of Total } \\
\text { Imports) }\end{array}$ & $\begin{array}{l}\text { Exports to } \\
\text { NZ } \\
\text { (\% of Total } \\
\text { Exports) }\end{array}$ & $\begin{array}{c}\text { Imports from } \\
\text { NZ } \\
\text { (\% of Total } \\
\text { Imports) }\end{array}$ \\
\hline & Average of 1998-2002 & - & 11.8 & 10.8 & 24.5 & 9.8 & 10.4 & 68.2 \\
\hline & 2003 & - & 4.9 & 4.3 & 6.9 & 6.6 & 21.0 & 78.2 \\
\hline & 2004 & - & 6.7 & 6.1 & 2.6 & 4.2 & 18.9 & 81.3 \\
\hline & 2007 & - & 18.0 & 17.5 & 3.7 & 6.2 & 15.5 & 66.4 \\
\hline \multirow[t]{5}{*}{ Fiji } & Average of 1994-1997 & 0.3 & 0.1 & 0.4 & 26.7 & 39.9 & 7.0 & 15.5 \\
\hline & Average of 1998-2002 & 6.8 & 0.1 & 3.0 & 20.3 & 43.2 & 3.9 & 14.6 \\
\hline & 2003 & 16.1 & 0.3 & 7.0 & 18.9 & 34.9 & 3.8 & 17.1 \\
\hline & 2004 & 16.0 & 0.4 & 6.9 & 18.6 & 25.9 & 3.4 & 21.2 \\
\hline & 2005 & 15.4 & 0.3 & 6.0 & 17.2 & 23.7 & 3.8 & 18.9 \\
\hline \multirow{5}{*}{ Kiribati } & 2003 & - & 27.5 & 18.7 & 1.8 & 41.0 & - & 8.8 \\
\hline & 2004 & - & 29.9 & 23.4 & 0.2 & 33.6 & - & 6.9 \\
\hline & 2005 & - & 27.1 & 25.4 & 0.4 & 33.3 & - & 6.9 \\
\hline & 2006 & & NA & NA & NA & NA & - & NA \\
\hline & 2007 & - & NA & NA & NA & NA & - & NA \\
\hline
\end{tabular}


Table 3. Intra-regional Exports and Imports of PICs (continued)

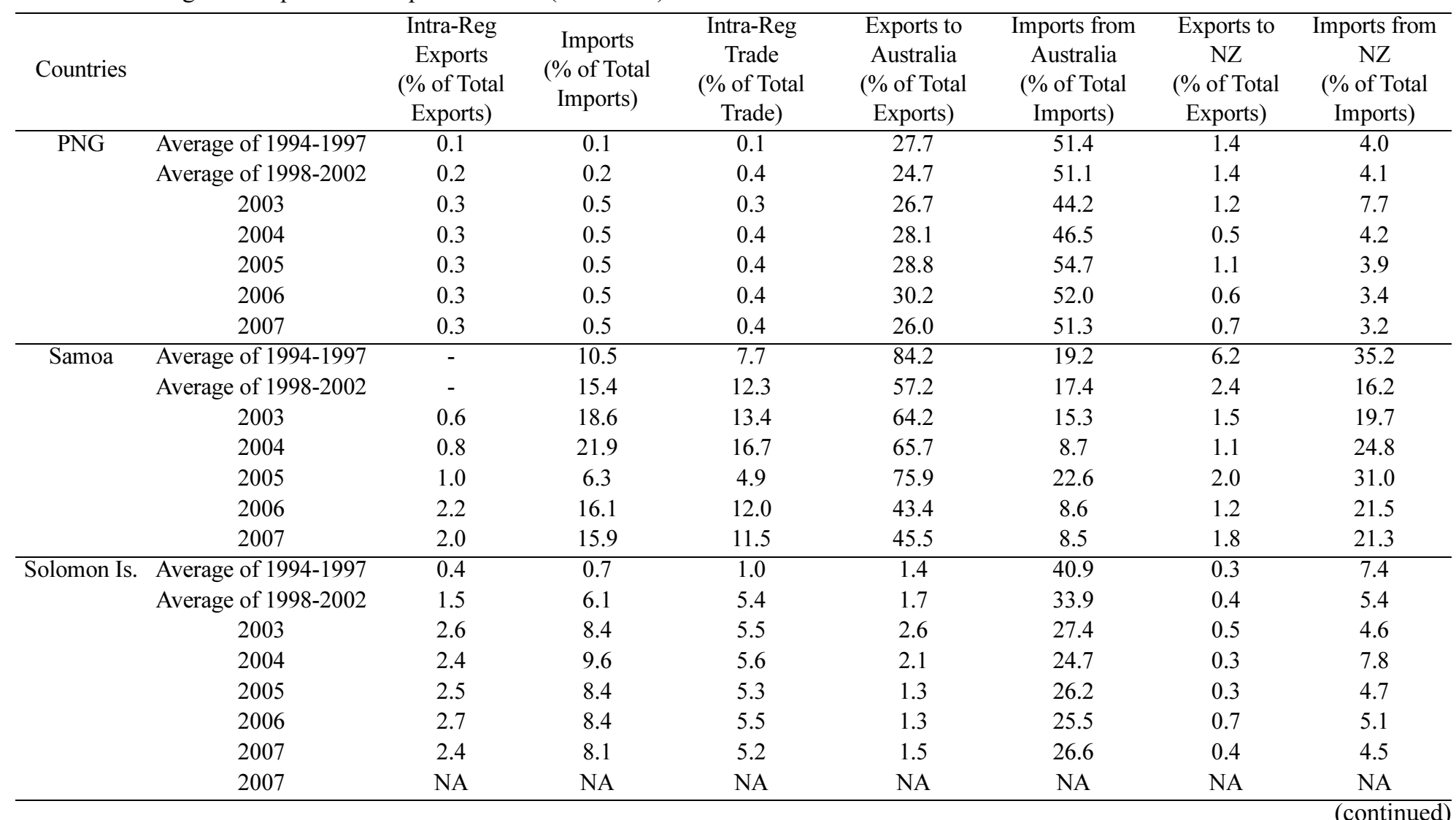


Table 3. Intra-regional Exports and Imports of PICs (continued)

\begin{tabular}{|c|c|c|c|c|c|c|c|c|}
\hline Countries & & $\begin{array}{l}\text { Intra-Reg } \\
\text { Exports } \\
\text { (\% of Total } \\
\text { Exports) }\end{array}$ & $\begin{array}{l}\text { Imports } \\
\text { (\% of Total } \\
\text { Imports) }\end{array}$ & $\begin{array}{l}\text { Intra-Reg } \\
\text { Trade } \\
\text { (\% of Total } \\
\text { Trade) }\end{array}$ & $\begin{array}{l}\text { Exports to } \\
\text { Australia } \\
\text { (\% of Total } \\
\text { Exports) }\end{array}$ & $\begin{array}{l}\text { Imports from } \\
\text { Australia } \\
\text { (\% of Total } \\
\text { Imports) }\end{array}$ & $\begin{array}{l}\text { Exports to } \\
\text { NZ } \\
\text { (\% of Total } \\
\text { Exports) }\end{array}$ & $\begin{array}{c}\text { Imports from } \\
\text { NZ } \\
\text { (\% of Total } \\
\text { Imports) }\end{array}$ \\
\hline \multirow[t]{7}{*}{ Tonga } & Average of 1994-1997 & 3.1 & 7.7 & 7.0 & 4.7 & 33.6 & 9.7 & 38.5 \\
\hline & Average of 1998-2002 & 2.9 & 14.1 & 12.1 & 2.5 & 15.9 & 6.8 & 32.2 \\
\hline & 2003 & 1.7 & 22.7 & 9.4 & 1.2 & 11.0 & 2.8 & 42.1 \\
\hline & 2004 & 2.6 & 24.9 & 9.6 & 1.1 & 9.2 & 7.4 & 34.8 \\
\hline & 2005 & 6.7 & 28.1 & 9.3 & 2.5 & 10.5 & 6.3 & 33.4 \\
\hline & 2006 & 7.3 & 32.0 & 9.8 & 2.0 & 7.5 & 8.2 & 27.7 \\
\hline & 2007 & NA & NA & NA & NA & NA & NA & NA \\
\hline \multirow[t]{6}{*}{ Tuvalu } & Average of 1994-1997 & 1.0 & 30.5 & 45.5 & - & 39.4 & - & 6.3 \\
\hline & Average of 1998-2002 & 8.2 & 60.3 & 57.0 & - & 20.2 & - & 5.8 \\
\hline & 2003 & 5.1 & 46.1 & 43.2 & 9.9 & 13.0 & - & 5.8 \\
\hline & 2004 & 17.6 & 50.2 & 49.2 & 0.2 & 9.6 & - & 5.5 \\
\hline & 2005 & 7.6 & 46.1 & 43.6 & 2.7 & 7.7 & - & 4.0 \\
\hline & 2006 & NA & NA & NA & NA & NA & NA & NA \\
\hline \multirow[t]{7}{*}{ Vanuatu } & Average of 1994-1997 & 0.1 & 0.9 & 0.9 & 4.1 & 21.0 & 0.5 & 5.2 \\
\hline & Average of $1998-2002$ & 2.5 & 6.0 & 6.2 & 1.6 & 22.7 & 0.6 & 6.7 \\
\hline & 2003 & 4.0 & 10.7 & 8.9 & 5.1 & 15.5 & 0.4 & 6.0 \\
\hline & 2004 & 1.9 & 12.3 & 7.4 & 1.2 & 16.7 & 0.4 & 7.3 \\
\hline & 2005 & 2.6 & 12.0 & 7.7 & 1.5 & 18.4 & 0.2 & 7.2 \\
\hline & 2006 & 2.2 & 14.7 & 8.8 & 1.0 & 20.6 & 0.2 & 8.8 \\
\hline & 2007 & NA & NA & NA & NA & NA & NA & NA \\
\hline
\end{tabular}

NA: Not availab

"-": negligible

Source: IMF (2008) 
of imports of Cook Islands, which is one of the least diversified PICs with negligible exports of goods but with heavy dependency on tourism, were sourced from New Zealand.

On the other hands, Fiji and PNG, which have some manufacturing base, have substantial trade with Australia and New Zealand. Nearly 25 per cent of Fiji's exports and 51 per cent of PNG's exports were directed to Australia. Thus, each PICs' trade with the any of the two advanced countries in the region has been substantial.

Aside from trade in goods, PICs, especially Cook Islands, Fiji, Samoa and Vanuatu are highly dependent on tourism. Most of the tourists to PICs have been traditionally from Australia and New Zealand. Further, in recent years, remittance inflows into PICS have been on the rise, as both Australia and New Zealand have relaxed their immigration conditions, with larger annual intake of skilled persons from PICs. Consequently, there has been a steady rise in remittance inflows to support their families and relatives in PICs.

Viewed against this background, it is increasingly recognized that regional output shocks, especially those of Australia and New Zealand, would have far reaching effects on PICs and hence would be a major factor for determining the suitability of each PICs' candidacy to be part of a regional currency union.

\section{Methodology and Data}

\section{A. Methodology}

Following Chow and Kim (2003), we estimate the output growth function subject to three different types of shocks, namely global, regional and countryspecific $\left(u^{g}, u^{r}\right.$ and $\left.u^{d}\right)$.

$$
\Delta y_{t}^{d}=\beta_{0}+\beta_{1}(L) u_{t}^{g}+\beta_{2}(L) u_{t}^{r}+\beta_{3}(L) u_{t}^{d}
$$

where $\beta_{i}(L)=\beta_{i 0}+\beta_{i 1} L+\beta_{i 2} L^{2}+\ldots$ is a polynomial function of the lag operator, $L$. Generally, global shocks affect economies both inside and outside the regional boundary. The oil price shock in the 1970s is an example of global shock. Regional shocks are generally common to economies within a region. On the other hand, country-specific shocks are unique to a particular economy, which may result from either aggregate demand shock (monetary or fiscal policy changes) or supply 
shocks on productivity or terms of trade (Bayoumi and Eichengreen, 1993).

The distinctions between these three shocks have significant, powerful policy implications. For example, if country-specific shocks are dominant and less correlated across the region, a member country of a currency union may be a loser, in the absence of monetary independence and freedom to resort to exchange rate adjustments. On the other side, if regional shocks affect all prospective member countries in the same manner, there is sufficient justification for a single set of common monetary and exchange rate policies within the region. In contrast, if global shocks are dominant and if they similarly affect all economies inside the region, a more global arrangement might be necessary. Nevertheless, as long as shocks influence all economies in a similar pattern, a global rather than regional policy arrangement may be a more appropriate course of action in dealing with such shocks.

In the Pacific region, for instance, if shocks in global output (U.S. output) impact PICs more than regional shocks (say Australian output shock), the formation of American dollar bloc may be a better policy choice than a formation of an Australian dollar bloc. Based on these explanations, it is indicated that a model of regional integration needs to consider a minimum of three types of shocks.

Considering a three-variable model with global, regional and local outputs: $y^{g}, y^{r}$ and $y^{d}$ They are related to three structural shocks as follows:

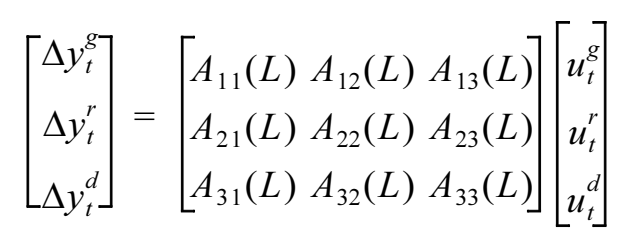

where $A_{i j}(L)=\alpha_{i j}^{0}+\alpha_{i j}^{1} L+\alpha_{i j}^{2} L^{2}+\ldots$ In the matrix form, $\Delta y_{t}=A(L) u_{t}$.

Following Chow and Kim (2003), it is assumed that the structural shocks are uncorrelated and of unit variance: $\operatorname{Var}\left(u_{t}\right)=I$. Since structural shocks are unobserved, few identifying restrictions need to be employed to recover them from reduced-form innovations. First, both regional and country-specific shocks have no long run relationship with global output. Second, country-specific shocks are uncorrelated with regional output in the long run. Generally, these restrictions are usually imposed on the small economy because an economy is viewed to be small in a region and the region is a small part of the global economy. Structural vector autoregression (VAR) technique, as proposed by Blanchard and Quah (1989) and King, et al. (1991) will be applied to estimate the above empirical model. The 
technique depends on the long-run impact of structural shocks derived from the neutrality of demand shocks. ${ }^{2}$

\section{B. Data}

In this study, output is represented by real gross domestic output (RGDP). Aside from Australia and New Zealand, six major PICs are studied. The choice of PICs is dictated by the availability of national accounts data series on a consistent basis. The PICs chosen are: Fiji, Papua New Guinea, Samoa, Solomon Islands, Tonga and Vanuatu. While the Australian output is used as a proxy for regional output, the US output represents the global output. All output data are in index form (Table 4) and the data sources are International Financial Statistics, International Monetary Fund (IMF) for RGDP data relating to Australia, New Zealand and the US; and UNESCAP (2007) and Asian Development Bank (2007) for RGDP relating to PICs.

Table 4. USA, Aus, NZ and PICS: Real GDP Index numbers Pacific Islands, Real GDP

\begin{tabular}{lccccccccccc}
\hline & 1981 & 1985 & 1990 & 1995 & 2000 & 2001 & 2002 & 2003 & 2004 & 2005 & 2006 \\
\hline USA & 100.0 & 114.3 & 134.0 & 151.4 & 185.3 & 186.8 & 190.3 & 196.2 & 204.4 & 211.6 & 218.6 \\
Aus & 100.0 & 112.3 & 130.5 & 153.1 & 185.4 & 192.6 & 198.7 & 206.3 & 212.5 & 217.8 & 223.7 \\
NZ & 100.0 & 113.3 & 116.7 & 135.8 & 154.3 & 159.7 & 167.0 & 173.1 & 180.7 & 184.7 & 187.4 \\
Fiji & 100.0 & 93.3 & 104.5 & 119.3 & 131.1 & 134.6 & 140.4 & 141.8 & 149.3 & 150.4 & 155.8 \\
PNG & 100.0 & 107.3 & 113.7 & 171.3 & 190.8 & 194.2 & 192.3 & 196.5 & 201.8 & 208.5 & 216.2 \\
Samoa & 100.0 & 104.6 & 108.4 & 114.4 & 137.4 & 147.0 & 148.5 & 153.7 & 159.3 & 167.5 & 173.3 \\
Sol. Is. & 100.0 & 119.6 & 167.2 & 217.6 & 190.0 & 173.5 & 169.8 & 180.7 & 195.1 & 204.9 & 217.6 \\
Tonga & 100.0 & 115.8 & 117.5 & 142.8 & 154.3 & 158.3 & 163.1 & 168.3 & 170.6 & 174.6 & 177.9 \\
Van- & 100.0 & 126.9 & 124.0 & 170.9 & 197.3 & 192.0 & 182.6 & 187.8 & 198.2 & 211.7 & 226.5 \\
uatu & & & & & & & & & & & \\
\hline
\end{tabular}

Source: IMF (2008), ADB (2007), UNESCAP (2007)

\footnotetext{
${ }^{2}$ Although such long-run restrictions tend to be less controversial and more readily accepted than other assumptions, they are not without criticisms. At least two criticisms have been made. First, Faust and Leeper (1997) argue that structural inferences under the long-run scheme may not be reliable as the long-run effects of shocks are imprecisely estimated in finite samples and the long-run identification scheme transfers this imprecision to the estimates of other parameters of the model. Second criticism is that the estimated disturbances are intertwined with the underlying disturbances.
} 
Table 5. Results of Unit Root Tests (Sample Period: 1981-2006)

\begin{tabular}{ccccc}
\hline \multirow{2}{*}{ GDP } & \multicolumn{2}{c}{ ADF Test } & \multicolumn{2}{c}{ Ng and Perron Test, MZa } \\
\cline { 2 - 5 } & $\begin{array}{c}\text { Level (Constant } \\
\text { with Trend) }\end{array}$ & $\begin{array}{c}\text { First Difference } \\
\text { (Constant } \\
\text { without Trend) }\end{array}$ & $\begin{array}{c}\text { Level (Constant } \\
\text { with Trend) }\end{array}$ & $\begin{array}{c}\text { First Difference } \\
\text { (Constant } \\
\text { without Trend) }\end{array}$ \\
\hline US & $-2.4020(0)$ & $-5.2199^{*}(0)$ & $-9.7780(1)$ & $-24.6035^{*}(5)$ \\
Australia & $-2.4881(0)$ & $-5.6786^{*}(1)$ & $-7.3209(1)$ & $-8.2985^{*}(2)$ \\
New Zealand & $-1.8646(1)$ & $-3.0367^{*}(0)$ & $-7.9403(1)$ & $-9.5529^{*}(0)$ \\
Fiji & $-2.2084(2)$ & $-7.5984^{*}(0)$ & $-7.4984(0)$ & $-7.9340^{*}(0)$ \\
PNG & $-2.2482(1)$ & $-3.7626^{*}(0)$ & $-12.2431(1)$ & $-11.5502^{*}(0)$ \\
Samoa & $-0.8479(1)$ & $-4.0592^{*}(0)$ & $-1.8885(0)$ & $-11.0951^{*}(0)$ \\
Solomon & $-1.9828(1)$ & $-3.3632^{*}(0)$ & $-5.0708(1)$ & $-11.1103^{*}(0)$ \\
Tonga & $-3.2707(2)$ & $-5.0089^{*}(0)$ & $-8.3452(2)$ & $-11.4452^{*}(0)$ \\
Vanuatu & $-2.1759(0)$ & $-4.3787^{*}(0)$ & $-6.5988(0)$ & $-10.6902^{*}(0)$ \\
\hline
\end{tabular}

Note: The ADF critical value at $5 \%$ level is -2.9640 and -3.5629 for constant without trend and constant with trend regressions, respectively. These critical values are based on Mckinnon. The optimal lag is selected on the basis of Akaike Information Criterion (AIC). The $\mathrm{Ng}$ and Perron critical value is based on Ng and Perron (2001) critical value and the optimal lag is selected based on Spectral GLS-detrended AR based on SIC. The null hypothesis of the test is: a series has a unit root. The asterisk * denotes the rejection of the null hypothesis at the $5 \%$ level of significance. The figures in brackets denote number of lags.

\section{Empirical Results}

As a first step, we tested the time series properties of each data series of RGDP of USA, Australia, New Zealand and six PICs. All the variables in levels contain unit root. However, test statistics reject the null of unit root at 5 per cent level of significance (Table 5). Thus, the series are of I(1).

In the presence of a non-stationary series, a cointegration test was performed using the Johansen and Juselius (1990) procedure. The test statistics indicated the presence of a long-run relationship in all PICs (Table 6.A and Table 6.B). Hence, all variables were entered in the VAR in levels, thereby resorting to the methodology of orthogonalized forecast error variance decomposition, which is based on Choleski factorization with particular ordering, namely: global output, regional output, and domestic output. Results of variance decomposition global, regional and country-specific shocks for a nine-year-ahead period with forecast errors are presented in Table 7.

The results indicate the strong influence of country-specific shock in regard to Fiji, Papua New Guinea and Tonga. In the one-year-ahead period, about 94.4 per cent of variability in Fiji's output is accounted for by variability in its own national 
Table 6a. Results of Johansen and Juselius Multivariate Procedure (Australia as Regional Shock)

\begin{tabular}{|c|c|c|c|c|}
\hline \multirow{2}{*}{ Hypothesis } & \multicolumn{2}{|c|}{ Maximum Eigenvalue } & \multicolumn{2}{|c|}{ Trace } \\
\hline & Test Statistic & $95 \%$ & Test Statistic & $95 \%$ \\
\hline \multicolumn{5}{|l|}{ Fiji } \\
\hline $\mathrm{P}=0$ & $25.21^{* *}$ & 21.13 & $34.93^{* *}$ & 29.80 \\
\hline $\mathrm{P} \leq 1$ & 9.55 & 14.26 & 9.72 & 15.49 \\
\hline $\mathrm{P} \leq 2$ & 0.17 & 3.84 & 0.17 & 3.84 \\
\hline \multicolumn{5}{|l|}{ PNG } \\
\hline $\mathrm{P}=0$ & $35.33^{* *}$ & 21.13 & $47.75^{* *}$ & 29.80 \\
\hline $\mathrm{P} \leq 1$ & 11.32 & 14.26 & 12.42 & 15.49 \\
\hline $\mathrm{P} \leq 2$ & 1.11 & 3.84 & 1.11 & 3.84 \\
\hline \multicolumn{5}{|l|}{ Samoa } \\
\hline $\mathrm{P}=0$ & $22.07^{* *}$ & 21.13 & $30.93^{* *}$ & 29.80 \\
\hline $\mathrm{P} \leq 1$ & 7.61 & 14.26 & 8.85 & 15.49 \\
\hline $\mathrm{P} \leq 2$ & 1.25 & 3.84 & 1.25 & 3.84 \\
\hline \multicolumn{5}{|l|}{ Solomon } \\
\hline $\mathrm{P}=0$ & $22.66^{* *}$ & 21.13 & $28.94^{*}$ & 29.80 \\
\hline $\mathrm{P} \leq 1$ & 5.07 & 14.26 & 6.28 & 15.49 \\
\hline $\mathrm{P} \leq 2$ & 1.21 & 3.84 & 1.21 & 3.84 \\
\hline \multicolumn{5}{|l|}{ Tonga } \\
\hline $\mathrm{P}=0$ & $20.96^{*}$ & 21.13 & $31.61^{* *}$ & 29.80 \\
\hline $\mathrm{P} \leq 1$ & 10.43 & 14.26 & 10.65 & 15.49 \\
\hline $\mathrm{P} \leq 2$ & 0.22 & 3.84 & 0.22 & 3.84 \\
\hline \multicolumn{5}{|l|}{ Vanuatu } \\
\hline $\mathrm{P}=0$ & $27.04^{* *}$ & 21.13 & $35.31^{* *}$ & 29.80 \\
\hline $\mathrm{P} \leq 1$ & 8.27 & 14.26 & 8.27 & 15.49 \\
\hline $\mathrm{P} \leq 2$ & 0.00 & 3.84 & 0.00 & 3.84 \\
\hline
\end{tabular}

Notes: ${ }^{*}$ and ${ }^{* *}$ indicates significant at $10 \%$ and $5 \%$ levels, respectively.

Critical values of trace and maximum eigenvalue according to Osterwald-Lenum (1992).

output, followed by Papua New Guinea ( 87.8 per cent) and Tonga (83.8 per cent). This is contrasted with the results in the case of Samoa, Solomon Islands and Vanuatu, where country-specific shocks account for a much lower proportion in their output variability ranging from 32.9 per cent to 49.5 per cent.

On the other hand, global output shock explains approximately 11.6 per cent of variance of output in PNG in the one-year-ahead and much less in all PICs, except Vanuatu. Nevertheless, by 9 years ahead, the explanations of the variance by global shock in these economies are quite stable, except for Fiji, which exhibits an increasing path. The variation in Fiji's output is explained by global shock for about 31.2 per cent in the 9-year ahead. 
Table 6b. Results of Johansen and Juselius Multivariate Procedure (New Zealand as Regional Shock)

\begin{tabular}{|c|c|c|c|c|}
\hline \multirow{2}{*}{ Hypothesis } & \multicolumn{2}{|c|}{ Maximum Eigenvalue } & \multicolumn{2}{|c|}{ Trace } \\
\hline & Test Statistic & $95 \%$ & Test Statistic & $95 \%$ \\
\hline \multicolumn{5}{|l|}{ Fiji } \\
\hline $\mathrm{P}=0$ & $40.90^{* *}$ & 21.13 & $52.38^{* *}$ & 29.80 \\
\hline $\mathrm{P} \leq 1$ & 11.27 & 14.26 & 11.48 & 15.49 \\
\hline $\mathrm{P} \leq 2$ & 0.21 & 3.84 & 0.21 & 3.84 \\
\hline \multicolumn{5}{|l|}{ PNG } \\
\hline $\mathrm{P}=0$ & $24.95^{* *}$ & 21.13 & $31.98^{* *}$ & 29.80 \\
\hline $\mathrm{P} \leq 1$ & 7.02 & 14.26 & 7.03 & 15.49 \\
\hline $\mathrm{P} \leq 2$ & 0.01 & 3.84 & 0.01 & 3.84 \\
\hline \multicolumn{5}{|l|}{ Samoa } \\
\hline $\mathrm{P}=0$ & $26.39^{* *}$ & 21.13 & $37.28^{* *}$ & 29.80 \\
\hline $\mathrm{P} \leq 1$ & 10.10 & 14.26 & 10.89 & 15.49 \\
\hline $\mathrm{P} \leq 2$ & 0.79 & 3.84 & 0.79 & 3.84 \\
\hline \multicolumn{5}{|l|}{ Solomon } \\
\hline $\mathrm{P}=0$ & $23.94^{* *}$ & 21.13 & $27.23^{*}$ & 29.80 \\
\hline $\mathrm{P} \leq 1$ & 3.28 & 14.26 & 3.29 & 15.49 \\
\hline $\mathrm{P} \leq 2$ & 0.01 & 3.84 & 0.01 & 3.84 \\
\hline \multicolumn{5}{|l|}{ Tonga } \\
\hline $\mathrm{P}=0$ & $29.75^{* *}$ & 21.13 & $42.17^{* *}$ & 29.80 \\
\hline $\mathrm{P} \leq 1$ & 12.42 & 14.26 & 12.42 & 15.49 \\
\hline $\mathrm{P} \leq 2$ & 0.01 & 3.84 & 0.01 & 3.84 \\
\hline \multicolumn{5}{|l|}{ Vanuatu } \\
\hline $\mathrm{P}=0$ & $21.84^{* *}$ & 21.13 & $29.60^{*}$ & 29.80 \\
\hline $\mathrm{P} \leq 1$ & 7.30 & 14.26 & 7.77 & 15.49 \\
\hline $\mathrm{P} \leq 2$ & 0.47 & 3.84 & 0.47 & 3.84 \\
\hline
\end{tabular}

The results show that variations in the real GDP of all PICs are increasingly explained by regional shocks (proxied by innovations in Australian real GDP) from 1-year ahead to 9-year ahead period: Fiji (1.6 per cent - 31.5 per cent), Papua New Guinea (0.6 per cent -40.7 per cent), Samoa (51.3 per cent -68.5 per cent), Solomon Islands (64.4 per cent -73.9 per cent), Tonga ( 16.5 per cent -38.5 per cent) and Vanuatu (4.5 per cent -59.5 per cent).

Using an alternative measure of regional shock, namely shocks in New Zealand's output, variance decomposition of PICs' real output is shown in Table 8. The results indicate that global shock still accounts for a small proportion of the yearly output variability at 1-year forecast horizon in Papua New Guinea, Solomon 
Table 7. Variance Decomposition of Real Output in PICs: 1981-2006 (Australian Output as Regional Output)

\begin{tabular}{|c|c|c|c|c|}
\hline Period & S.E. & Global Output & Regional Output & Country output \\
\hline \multicolumn{5}{|l|}{ Fiji } \\
\hline 1 & 0.031 & 3.979 & 1.596 & 94.425 \\
\hline 3 & 0.039 & 10.257 & 25.815 & 63.928 \\
\hline 5 & 0.044 & 18.080 & 31.208 & 50.712 \\
\hline 7 & 0.048 & 25.273 & 31.900 & 42.827 \\
\hline 9 & 0.052 & 31.217 & 31.366 & 37.417 \\
\hline \multicolumn{5}{|c|}{ Papua New Guinea } \\
\hline 1 & 0.054 & 11.622 & 0.612 & 87.767 \\
\hline 3 & 0.094 & 7.291 & 24.144 & 68.565 \\
\hline 5 & 0.116 & 6.229 & 42.289 & 51.482 \\
\hline 7 & 0.118 & 8.449 & 41.306 & 50.245 \\
\hline 9 & 0.119 & 9.586 & 40.656 & 49.758 \\
\hline \multicolumn{5}{|l|}{ Samoa } \\
\hline 1 & 0.034 & 3.844 & 51.294 & 44.862 \\
\hline 3 & 0.050 & 3.370 & 59.416 & 37.214 \\
\hline 5 & 0.065 & 3.655 & 64.459 & 31.886 \\
\hline 7 & 0.072 & 3.685 & 68.035 & 28.281 \\
\hline 9 & 0.073 & 3.645 & 68.478 & 27.877 \\
\hline \multicolumn{5}{|c|}{ Solomon Islands } \\
\hline 1 & 0.052 & 2.681 & 64.358 & 32.961 \\
\hline 3 & 0.095 & 1.286 & 79.236 & 19.478 \\
\hline 5 & 0.104 & 10.479 & 72.300 & 17.221 \\
\hline 7 & 0.138 & 15.160 & 74.095 & 10.745 \\
\hline 9 & 0.147 & 16.424 & 73.893 & 9.683 \\
\hline \multicolumn{5}{|l|}{ Tonga } \\
\hline 1 & 0.024 & 0.676 & 16.541 & 82.784 \\
\hline 3 & 0.035 & 4.017 & 14.834 & 81.149 \\
\hline 5 & 0.040 & 5.113 & 31.207 & 63.680 \\
\hline 7 & 0.043 & 4.881 & 36.370 & 58.749 \\
\hline 9 & 0.046 & 5.420 & 38.554 & 56.026 \\
\hline \multicolumn{5}{|l|}{ Vanuatu } \\
\hline 1 & 0.029 & 45.969 & 4.538 & 49.494 \\
\hline 3 & 0.067 & 17.268 & 54.590 & 28.143 \\
\hline 5 & 0.078 & 12.978 & 59.038 & 27.985 \\
\hline 7 & 0.079 & 13.284 & 59.374 & 27.342 \\
\hline 9 & 0.081 & 14.383 & 59.457 & 26.160 \\
\hline
\end{tabular}

Cholesky Ordering: Global output, Regional output, Country-specific output 
Table 8. Variance Decomposition of Real Output in Pacific Island Countries (PICs), 1981 2006, (New Zealand Output as Regional Output)

\begin{tabular}{ccccc}
\hline Period & S.E. & Global Output & Regional Output & Country Output \\
\hline Fiji & & & & \\
1 & 0.031 & 48.234 & 42.231 & 9.535 \\
3 & 0.036 & 55.250 & 37.258 & 7.493 \\
5 & 0.038 & 55.236 & 37.570 & 7.194 \\
7 & 0.044 & 64.342 & 29.348 & 6.310 \\
9 & 0.047 & 67.570 & 26.364 & 6.065 \\
Papua New Guinea & & & & \\
1 & 0.050 & 3.209 & 13.437 & 83.354 \\
3 & 0.080 & 3.303 & 7.214 & 89.483 \\
5 & 0.088 & 6.190 & 10.102 & 83.708 \\
7 & 0.092 & 8.574 & 13.581 & 77.845 \\
9 & 0.095 & 10.005 & 13.914 & 76.081 \\
Samoa & & & & \\
1 & 0.030 & 21.637 & 15.276 & 63.087 \\
3 & 0.051 & 27.117 & 45.084 & 27.798 \\
5 & 0.071 & 39.942 & 45.118 & 14.939 \\
7 & 0.080 & 41.532 & 45.209 & 13.259 \\
9 & 0.082 & 40.937 & 45.906 & 13.157 \\
Solomon Islands & & & & \\
1 & 0.034 & 0.676 & 19.758 & 79.566 \\
3 & 0.088 & 16.030 & 23.824 & 60.146 \\
5 & 0.099 & 16.889 & 22.776 & 60.335 \\
7 & 0.103 & 18.048 & 25.013 & 56.938 \\
9 & 0.115 & 21.162 & 31.413 & 47.425 \\
Tonga & & & & \\
1 & 0.020 & 7.938 & 11.457 & 80.605 \\
3 & 0.035 & 23.278 & 42.578 & 34.143 \\
5 & 0.043 & 34.789 & 40.966 & 24.245 \\
7 & 0.047 & 39.835 & 39.182 & 20.982 \\
9 & 0.051 & 42.564 & 38.355 & 19.081 \\
Vanuatu & & & & \\
1 & 0.055 & 7.571 & 29.942 & 62.487 \\
3 & 0.079 & 9.535 & 25.107 & 65.358 \\
5 & 0.083 & 9.627 & 26.328 & 64.044 \\
7 & 0.086 & 11.431 & 28.866 & 59.703 \\
9 & 0.089 & 12.892 & 30.356 & 56.751 \\
\hline
\end{tabular}

Cholesky Ordering: Global output, Regional output, Country-specific output 
Table 9. Variance Decomposition of Real Output in Australia, 1981-2006

\begin{tabular}{ccccc}
\hline Period & S.E. & $\begin{array}{c}\text { (Global Output) } \\
\text { United States }\end{array}$ & $\begin{array}{c}\text { (Regional Output) } \\
\text { New Zealand }\end{array}$ & $\begin{array}{c}\text { (Country-specific) Aus- } \\
\text { tralia }\end{array}$ \\
\hline 1 & 0.010 & 37.873 & 0.000 & 62.127 \\
3 & 0.023 & 30.484 & 10.347 & 59.169 \\
5 & 0.034 & 28.687 & 18.257 & 53.057 \\
7 & 0.042 & 27.693 & 21.494 & 50.814 \\
9 & 0.049 & 27.425 & 22.920 & 49.656 \\
\hline
\end{tabular}

Cholesky Ordering: Global output, Regional output, Country-specific output

Table 10. Variance Decomposition of Real Output in New Zealand, 1981-2006

\begin{tabular}{ccccc}
\hline Period & S.E. & $\begin{array}{c}\text { (Global Output) } \\
\text { United States }\end{array}$ & $\begin{array}{c}\text { (Regional Output) } \\
\text { Australia }\end{array}$ & $\begin{array}{c}\text { (Country-Specific) } \\
\text { New Zealand }\end{array}$ \\
\hline 1 & 0.014 & 6.357 & 6.392 & 87.251 \\
3 & 0.028 & 4.523 & 31.108 & 64.369 \\
5 & 0.039 & 5.814 & 32.394 & 61.792 \\
7 & 0.048 & 8.172 & 33.445 & 58.383 \\
9 & 0.056 & 10.214 & 34.646 & 55.141 \\
\hline
\end{tabular}

Cholesky Ordering: Global output, Regional output, Country-specific output

Islands and Vanuatu. However, it increases over time and accounts for a sizeable proportion of variability in national output of Fiji (67 per cent), Samoa (40.9 per cent) and Tonga (42.6 per cent). Further, consistent with the results reported in Table 6, the country-specific shock explains substantially a larger proportion of output variability in all PICs at the first-year-ahead forecast horizon, except for Fiji. These results imply that PICs are not to a great extent influenced by global and regional shocks in the short-term. However, the influence of country-specific shock is on the decline over the 9-year forecast horizon. Furthermore, the results show that the regional shock accounts for a large proportion of national output variability in all PICs at the one-year-ahead forecast. The influence of regional shock (when proxied by New Zealand's output variability) on national output is increasing over time, more than 20 per cent in all PICs except Papua New Guinea at the 9-yearahead forecast.

Thus, the variance decomposition results reveal that in the short-run, PICs are greatly influenced by their own country-specific shocks and are less vulnerable to regional and global shocks.

Tables 9 and 10 focus exclusive attention on Australia and New Zealand. These 
two countries, unlike PICs have much deeper trade and investment relations, perfect mobility in capital and labour between themselves. However, we observe that variability in their national outputs is greatly explained by their own specific shocks, not only in the short term, but also in the long term. Furthermore, it is noted that these two countries experience asymmetric shocks in respect to global developments, as global shocks explain a larger proportion of the yearly forecast error in Australia than in New Zealand.

\section{Summary and Conclusions}

This paper re-visited the study undertaken earlier by Ward and Jayaraman Ward (2006). Specifically, this paper investigated whether PICs can form a currency union with Australia and New Zealand by considering shocks in regional and global outputs and country output. Employing the methodology of variance decomposition with two different proxy measures for regional output, namely Australian and New Zealand output) shock, we find that (i) most of the variability in PICs's domestic outputs in the short- and medium terms appears to be largely explained by their own country-specific output shocks; (ii) the influence of domestic shock on PICs respective output declines over the 9-year period; (iii) the decreasing influence of country-specific shock in explaining the variability in domestic outputs in all PICs is accompanied by an increasing influence of regional shock in these economies; (iv) the role of global shock appears to be of less importance in explaining the variability of domestic output in most PICs; and (v) variability in Australian output has much greater influence on PICs than variability in New Zealand's output on PICs' domestic outputs.

The conclusion that emerges from the foregoing discussion is that since these economies are strongly affected by their own country-specific conditions, PICs are not presently suitable candidates for a currency union either amongst themselves or with any of the two advanced countries in the region. The variability in domestic outputs of PICs seems to result from their own aggregate demand shocks (monetary or fiscal policy changes) or domestic supply shocks, stemming from natural disasters and other unforeseen unstable conditions, including political uncertainties. Despite sharing several commonalities in terms of openness and other unique cultural characteristics such as communal land tenure, PICs are apparently quite different from each other, because of the diversity in institutional factors and political trends, resulting in asymmetric domestic output shocks. 
Since the influence of Australia on PICs has been substantial and the evidence of an increasing role for a global currency is relatively faint, it is obvious that regional output shocks would continue to be dominant. In these circumstances, although a currency union in the region cannot be justified in the short-term, there is a strong case for these economies to forge a regional currency bloc, which can ultimately blossom into a currency union, provided there is a steady progress toward closer economic cooperation between PICs envisaged under the Pacific Island Countries Trade Agreement signed and ratified by PICs, which is expected to take effect from January 1, 2010 and Pacific Agreement on Closer Economic Relations, which would be effective from January 2015.

\section{Acknowledgments}

The authors express their thanks to an anonymous referee and the Editor for their constructive criticisms on an earlier version of the article.

Received 30 January 2008, Revised 23 October 2008, Accepted 5 November 2008

\section{References}

Alesena, A. and R. Barro (2001), "One Country, One Currency”, in Alesena, A., Barro, R., (eds.) Currency Unions, Stanford, Hoover Institution, pp.11-20.

Asian Development Bank (ADB) (2007), "Key Indicators of Asian and Pacific Developing Countries 2001", Asian Development Bank, Manila.

Australian Senate Committee Report (2003), "A Pacific Engaged: Australia's Relations with Papua New Guinea and the Island States of the Southwest Pacific", Commonwealth of Australia, Canberra.

Bayoumi, T. and B. Eichengreen (1993), "Shocking Aspects of European Monetary Unification”, NBER Working Paper, No. 3949.

Bayoumi, T. and B. Eichengreen (1994), "One Money or Many? Analyzing the Prospects for Monetary Unification in Various Parts of the World", Princeton's Studies in International Finance, No.76, September.

Bayoumi, T., B. Eichengreen and P. Mauro (2000), "The Suitability of ASEAN for a Regional Currency Arrangement”, IMF Working Paper WP/99/162, IMF, Washington, D.C.

Bayoumi T. and P. Mauro. (1999), "The Suitability of ASEAN for a Regional Currency Arrangement", IMF Working Paper WP/99/162, International Monetary Fund, Washington, D.C.

Blanchard, O.J. and D. Quah (1989), “The Dynamic Effects of Aggregate Demand and 
Supply Disturbances", American Economic Review, 79, 655-73.

Bowman, C. (2004), "Pacific Island Countries and Dollarisation", Pacific Economic Bulletin, 19, 115-32.

Brash, D. (2000), "The Pros and Cons of Currency Union: A Reserve Bank Perspective, An Address to the Auckland Rotary Club, 22 May 2000", http://www.rbnz.govt.nz/ speeches/0091114.html

Bunyaratavej, K. and T.K. Jayaraman (2007), "Are the Pacific Islands Ready for a Single Currency?”, Journal of Developing Areas, 40, 141-156.

Chand, S (2003), "An Assessment of the Proposal for a Pacific Economic and Social Community", Pacific Economic Bulletin, 18, 117-24.

Chow, H.K. and Kim, Y. (2003), "A Common Currency Peg in East Asia? Perspectives from Western Europe", Journal of Macroeconomics, 25, 331-50.

Coleman, A, (1999), "Economic Integration and Monetary Union", New Zealand Treasury Working Paper 99/6, Government of New Zealand Treasury, Wellington.

Commonwealth of Australia (2008), Pacific Economic Survey 2008, Public Affairs Group, Commonwealth of Australia, Canberra.

Commonwealth of Secretariat (2006), Small States: Economic Review and Basic Statistics, 13, Commonwealth Secretariat, London.

Crossby, M. and G. Otto (2003), "An Australia and New Zealand Currency Union”, University of Melbourne, http://www.economics.unimelb.edu.au/mcrosby/ANZ.PDF De Brouwer, G. (2000), Should Pacific Island Countries Adopt the Australian dollar? Pacific Economic Bulletin, 15, 161-69.

Duncan, R. (2002), Dollarizing the Solomon Islands Economy, Pacific Economic Bulletin, $17,143-46$.

Duncan, R. (2005), “A Common Currency for the Pacific Island Economies”, in Chand, (ed.) S., Pacific Islands Regional Integration and Governance, The Australian National University, Canberra. 115-118.

Eichengreen, B. and T. Bayoumi (1999), "Is Asia an Optimum Area? Can it Become One?, in Collignon, S., Pisani-Ferry, J., Park, Y.C., Exchange Rate Policies in Emerging Asian Countries, Routledge, London.

Faust, J., and E.M. Leeper (1997), When do long-run restrictions give reliable results?, Journal of Business and Economic Statistics, 15, 345-53.

Grimes, A., F. Holmes and R. Bowden (2000), An Anzac Dollar? Currency Union and Business Development, Institute of Policy Studies, Wellington, New Zealand.

Hargreaves, D. and J. McDermott (1999), "Issues relating to Optimal Currency Areas: Theory and Implications for New Zealand", Reserve Bank of New Zealand Bulletin, 62, 16-29.

Hughes, H. (2003), Aid has Failed in the Pacific, Issue Analysis No.33, The Centre for Independent Studies, Sydney.

International Monetary Fund (IMF) (1997), Optimum Currency Areas: New Analytical and Policy Developments, IMF, Washington, DC.

IMF (2001), "International Experience with Common Currency Arrangements", Paper 
presented at the Seminar on Common Currency Arrangements and the Exchange Rate Mechanism in ASEAN, August 6-7, Kuala Lumpur.

IMF (2007), International Financial Statistics Yearbook 2007, IMF, Washington, D.C. IMF (2008) Directions of Trade, IMF, Washington, D.C.

Jayaraman, T.K. (2001), "Prospects for a Currency Union in the Pacific: A Preliminary Assessment", The Journal of Pacific Studies, 25, 173-201.

Jayaraman, T.K. (2003), "Is there a Case for a Single Currency for the South Pacific Island Countries?", Pacific Economic Bulletin, 18, 41-53.

Jayaraman, T.K. (2004), "A Single Currency for the Pacific Island Countries: A Stepwise Approach”, Asia-Pacific Development Journal, 11, 91-111.

Jayaraman, T. K. (2005), "Dollarisation of Pacific Island Countries: A Feasibility Study", Perspectives in Global Development and Technology, 4, 197-228.

Jayaraman, T.K. (2006), "Patterns of Shocks and Regional Currency for the Pacific Islands", Journal of Economic Integration, 21, 99-119.

Jayaraman, T.K., B.D. Ward and Z. L. Lu (2007), Are Pacific Islands Ready for a Currency Union? An Empirical Study of Degree of Economic Convergence, Journal of Asia and Pacific Economy, 12, 504-21.

Johansen, S. and K. Juselius (1990), "Maximum Likelihood Estimation and Inference on Cointegration - with Application to the Demand for Money", Oxford Bulletin of Economics and Statistics, 52, 169-210.

King, R.G., C.I. Plosser, J.H. Stock and M. Watson (1991), "Stochastic Trends and Economic Fluctuations", American Economic Review, 81, 819-40.

Mundell, R., (1961), A Theory of Optimum Currency Areas, American Economic Review, 51, 657-65.

Ng, S. and P. Perron (2001), "Lag Length Selection and the Construction of Unit Root Tests with Good Size and Power", Econometrica, 69, 1519-54.

Osterwald-Lenum, M. (1992), "A Note with Quantiles of the Asymptotic Distribution of the Maximum Likelihood Cointegration Rank Test Statistics", Oxford Bulletin of Economics and Statistics, 54, 461-72.

UNESCAP (2007), Economic and Social Survey of Asia and Pacific 2007, UNESCAP, Bangkok.

Ward, B.D. and Jayaraman. T.K. (2006), "Single Currency for the Pacific Island States: An SVAR Approach", Economia Internazionale, LIX, 82-111.

World Bank, (2006), World Development Indicators, CD ROM, 2006. 